\title{
Andesite and obsidian accessibility and distribution during the Holocene in north-west Santa Cruz province (south- central Patagonia), Argentina
}

\author{
Mariana Sacchi ${ }^{1,2}$, Damián Bozzuto ${ }^{1,2,3}$, Ana Gabriela Guraieb ${ }^{1,2}$, \\ María Teresa Civalero ${ }^{1,2,3}$, Nicolás Maveroff ${ }^{1,2}$ \\ 1. Instituto Nacional de Antropología y Pensamiento Latinoamericano (INAPL). 3 de Febrero 1378 - 1426 \\ Ciudad Autónoma de Buenos Aires, Argentina. Email: Sacchi: sacchi.mariana@gmail.com; \\ Guraieb: gabriela.guraieb@inapl.gob.ar; Maveroff: nicolasmaveroff@gmail.com; \\ Bozzuto: damianbozzuto@gmail.com, Civalero: mtcivalero@gmail.com \\ 2. Universidad de Buenos Aires (UBA), Buenos Aires, Argentina. \\ 3. Consejo Nacional de Investigaciones Científicas y Técnicas (CONICET), Buenos Aires, Argentina.
}

\begin{abstract}
:
This paper discusses different aspects related to the andesite and obsidian availability and circulation routes in different moments of the occupation sequence in the Pueyrredón-PosadasSalitroso (PPS) Lake Basin in the north, and the Burmeister-Belgrano (BB) Lake Basin to the south (north-west Santa Cruz province, Argentinian Patagonia).

The distribution of raw materials - both in space and time - allows us to assert that potential regional circulation routes would have been affected differentially by the palaeolakes present from the Pleistocene up until the mid-Holocene. We are taking into account three sites: Cueva Milodón Norte 1 (CMN1), located in the northeast coast of the Pueyrredón Lake, Cerro de los Indios 1 (CI1) (central portion of the PPS Basin), and Cerro Casa de Piedra 7 (CCP7) (near to the Burmeister Lake). This investigation considers six periods, based on the calibrated ranges from 73 radiocarbon dates: 17 from CI1, 14 from CMN1, and 42 radiocarbon dates from CCP7.

As a result of this analysis we can conclude that, in sites with a higher density of occupation such as CI1 and CCP7, the use of obsidian (non-local rock) and andesite or basalt did not vary over time. In the case of CMN1, access to the sources of these raw materials varied according to the presence of large bodies of water, although it does not seem to have influenced the procurement of these rocks.
\end{abstract}

Keywords: Patagonia; palaeolakes; access; obsidian; basalt; andesite

\section{Introduction}

\subsection{Palaeolakes and human movements}

In the southern Andean Range, a rapid warming after ca. 15500 cal. years BP triggered a period of climatic fluctuations and retreating glaciers (Glasser et al. 2004). Northern and Southern Patagonian Ice Fields were separated ca. 11400 years BP; previously, both were part

Published by the School of History, Classics and Archaeology, University of Edinburgh ISSN: 2055-0472. URL: http://journals.ed.ac.uk/lithicstudies/

Except where otherwise noted, this work is licensed under a CC BY 4.0 licence. 
of a single Ice Field that obstructed the course of the Baker River (Chile) (Mc Cullough et al. 2000).

Towards the end of the Pleistocene up until the mid-Holocene, big palaeolakes created by the contraction of mountain glaciers filled the space that had been previously covered by ice. One of them occupied the present basin of the Burmeister-Belgrano-Nansen-Azara-MogoteVolcán lacustrine system (BB). Around ca. 6900 BP it reached its highest level (900 m ASL) (Gonzalez 1990; 1992; Horta et al. 2017); meanwhile the latest evidence of drainage are ca. 2200 cal. years old (Aschero et al. 2005; Cassiodoro et al. 2013). Today, Lake Burmeister drains to the Atlantic Ocean through River Roble, while Lake Belgrano drains to the Pacific Ocean (Figure 1).

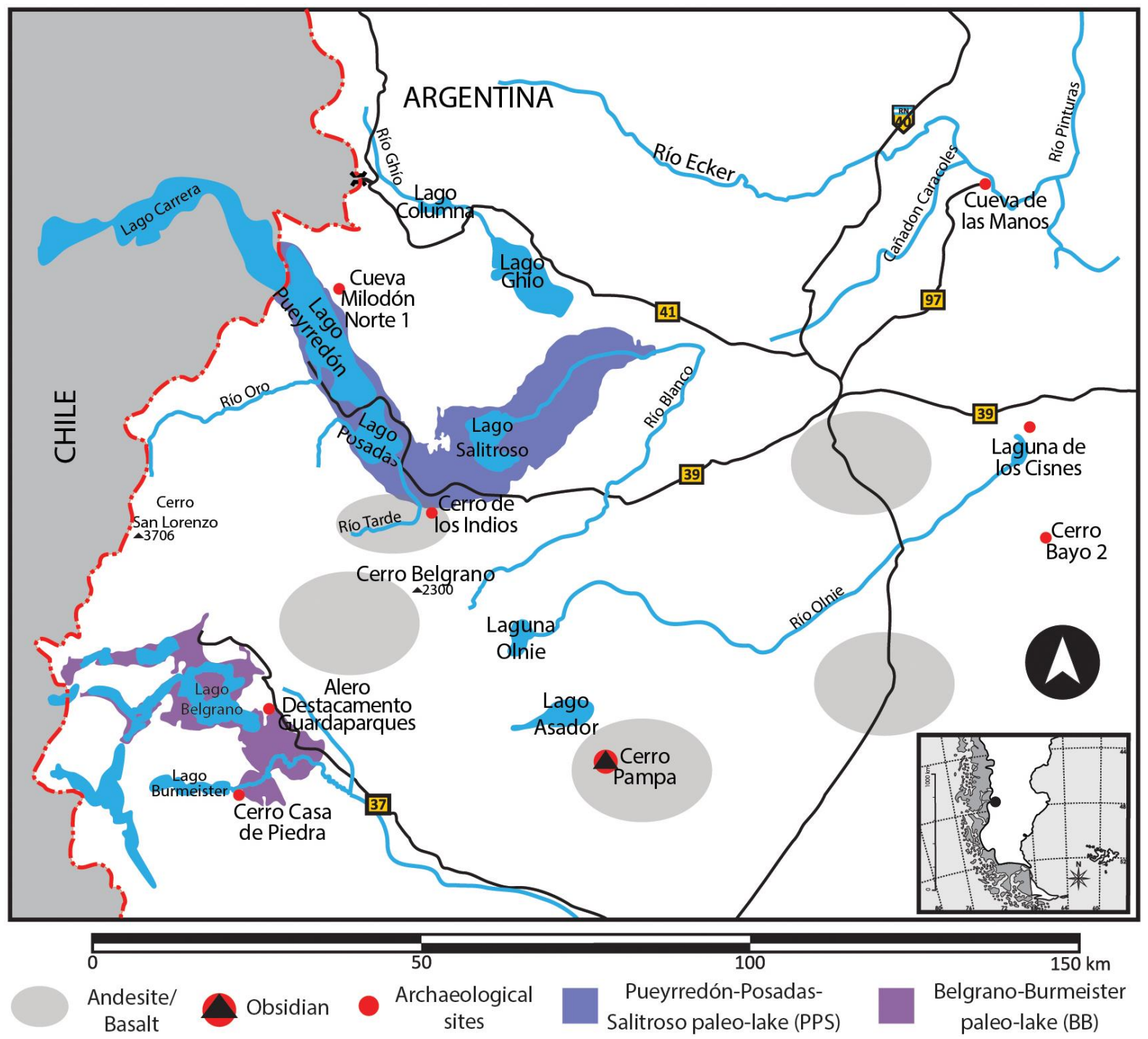

Figure 1. NW of Santa Cruz province, with the inferred extension of palaeolakes, archaeological sites and andesite and obsidian sources mentioned in the text.

To the northwest, at a lesser altitude above sea level than the Burmeister-Belgrano Basin, another big palaeolake occupied the Cochrane (Chile)-Pueyrredón-Posadas-Salitroso Basin, shaping a single lacustrine system. This palaeolake was active with variable spatial coverage and different degrees of ponding between 11400 and $2200 \mathrm{cal}$. BP. These days, Lake Posadas and Lake Pueyrredón drain to the Pacific Ocean and to the east while the closed system of Lake Salitroso is fed by the Blanco River. The later and progressive drainage of these two big 
palaeolakes, which began around 5900 years BP, was characterized by a series of fast and slow episodes of runoff. Fluvioglacial, glaciolacustrine moraine deposits, and U-shaped valleys are evidence of its glacial origin (Horta \& Aschero 2010; Horta \& Gonella 2009; Horta et al. 2016; Pereyra 1997). Picture 1 features a projection of the maximum extension reached by both lacustrine systems according to palaeoenvironmental indicators registered by Horta and compared to the current extension of the lacustrine system of the PosadasPueyrredón-Salitroso Lake in the northwest and the Burmesiter-Belgrano Lake.

Human circulation and available resources may have been altered by some naturalcaused factors such as the presence of barriers or other circulation impediments resulting in the need of long detours to access some environments and specific resources. Although the environment does not mechanically determine the responses in social organizations, it does constrain the set of strategies that can be implemented (Morales et al. 2009). Although not yet resolved, from an archaeological perspective timing and speed of drainage events have a significant importance in order to assess regional circulation and the election of certain landscapes for residential settlements (Bozzuto 2011; Carozza et al. 2012; Guraieb 2012).

\subsection{Research question}

This paper inquires about the possibility that the drainage of cordilleran palaeolakes could have shaped the circulation, availability and acquisition of andesite and obsidian at a regional scale during the Early and Middle Holocene periods. Archaeological sites in NW Santa Cruz could have been affected by the reduction in available residential space and possible routes to certain lithic procurement sources.

We take into consideration different periods of the chronological sequence of three multicomponent residential sites. Cerro de los Indios 1 (CI1) is located at the southern margin of the Posadas-Pueyrredón-Salitroso Basin (PPS), Cueva Milodon Norte 1 (CMN1) at the northeast margin of the same basin, and Cerro Casa de Piedra 7 (CCP7), situated at the southern margin of the Burmeister-Belgrano Basin (Figure 1). All three were occupied at different moments during Holocene times. Thus, lithic records of some periods of these three sites should expose restrictions in regional mobility, revealing distinctive strategies of raw material selection and use throughout time.

\subsection{Previous researches}

Except for few published notes (Molina 1971) and a single archaeological campaign in Cerro de los Indios 1 (CI1) in 1977, research in the PPS Basin has been carried out on a regular base since 1991 until today. At the same time, archaeological research on the cordilleran region of the NW of Santa Cruz begun in the mid-1980s and has intensified since then.

In an attempt to compare archaeological variability at a larger regional scale, during the 1980s and the 1990s both basins were included in a single project. This area encompassed Perito Moreno National Park (PNPM) and the high plateaus to the northeast (Plateaus Del Águila, De la Chispa and Del Asador). Towards the north, sub-area Posadas Lake included the entire PPS Basin. The international limit with Chile was its western border (Aschero et al. 1992).

The PPS Basin is the lowest of the entire region (100 to $300 \mathrm{~m}$ ASL), making its climate far more benign for human occupation than any other contiguous areas. Different authors have proposed this basin to be a very suitable landscape to establish permanent or semipermanent residential settlements during late Holocene, also known as a period of regional increase of aridity (Goñi 2000). 
Other teams began researching the archaeological record of different topographic units within the basin, thus increasing the archaeological information from the late huntergatherers' settlements (Aragone et al. 2004; Re 2006). Towards the eastern border of the basin, the closed system of Lake Salitroso concentrates the largest and most extensive burial area in the region, generally with just one or very few structures (García Guraieb et al. 2015). Its study provided relevant information about burial practices of Late Holocene huntergatherers (Cassiodoro et al. 2004; Goñi et al. 2002).

In the same basin, research on the northern bank of Lake Pueyrredón started in 2005 to establish directions and particularities of regional human peopling (Aschero et al. 2007; Bozzuto 2008). When CI1 was first occupied, only a part of the basin was available to the circulation below $300 \mathrm{~m}$ ASL. Previously, with the palaeolake at its maximum level, settlements as CMN1, located on the shore or nearby, had a much more restricted circulation across the landscape (Bozzuto 2011).

In the Burmeister-Belgrano Basin, archaeological research identified two well-defined occupation spans (Early and Late periods) and an archaeological record selectively distributed in the landscape. Residential mobility characterized the Early period while a logistic use of landscape (sensu Binford 1981) defined the Late period. The presence of a big palaeolake caused a restriction on circulation routes and the possibility of access to certain places and resources (Aschero et al. 2005; González 1990; 1992).

\section{Methods}

\subsection{Raw materials considered}

There are mainly three kinds of rocks represented amongst lithic raw materials of the archaeological record of the Pueyrredón-Posadas-Salitroso Basin: basalt or andesite, obsidian and different varieties of siliceous rocks. Other lithologies can be found as well but are significantly less abundant: different varieties of rhyolite (more or less vitreous), siltstone, dacites, silicified tuff, and non-identified vulcanite varieties. In the Burmeister-Belgrano Basin, obsidian is the most represented rock, followed by rhyolites, basalts, and siliceous rocks.

Most of these come from secondary sources (sensu Nami 1992), concentrations of variable size of good quality boulders and pebbles, eroded, disintegrated, and transported from its original outcrops due to glacial or fluvial action as well as the combination of both agents. Those processes affected the Andean landscape of NW Santa Cruz province during the Pleistocene and its transition into the Holocene (Pereyra \& Guraieb 1998a; 1998b).

This analysis will only compare the accessibility and distribution of obsidian and basalt or andesite due to the fact that both raw materials have well-identified acquisition sources. This allows inferring routes and accessibility related to changes in levels and drainages of both lacustrine basins. On the contrary, siliceous rocks, the most represented lithology within a third category called "Others" which also includes rhyolite, siltstone, and less abundant raw materials, are pebbles and boulders mostly ubiquitous in the landscape.

\subsubsection{Basalt, Posadas andesite or andesite}

A black rock with plagioclase phenocrysts immersed in a vitreous and more or less opaque paste is one of the most abundant raw materials in many lithic assemblages of the PPS Basin. It was originally called "Posadas basalt" (sensu Ramos 1982; Riggi 1957). Due to its texture, mineralogical analyses pose some difficulties for microscopic identification, therefore requiring a chemical classification (Tivoli 2004; Tivoli 2005). Different authors have stated 
that andesite is much more acidic than the Posadas basalt although these are macroscopically and petrographically similar (Mahlburg Kay et al. 1993; Ramos et al. 2004).

This particular difficulty led Dr. Charles Stern to perform geochemical analyses on three basalt samples: from CI1 site, from a secondary source located on a terrace near River Tarde $3.5 \mathrm{~km}$ to the west of CI1, and from the Chilean Chacabuco area. Chemical ranges (in ppm) revealed provenience relationships between those three sets of samples.

Major geochemical elements analyses showed that all samples had 62-67\% of $\mathrm{SiO}_{2}$. Basalts percentages of $\mathrm{SiO}_{2}$ are clearly under $52 \%$, so the former Posadas basalt begun to be called "Posadas andesite" in Chilean literature (Méndez et al. 2004, and others) or simply "andesite" (Guraieb et al. 2006).

We assume that basalt and andesite varieties have a wide distribution throughout the whole regional landscape. For instance, as a result of a later retroarc magmatic outpouring, there is a discrete adakite outcrop in the Cerro Pampa area, the same location where obsidian comes from. Adakite is an andesite of Miocenic origin, much younger than the Posadas basalt, and part of an outcrop of acidic magmatic bodies (rhyolitic, dacitic, and andesitic) the same as the Iglesia and Ventana hills (Ramos et al. 2004).

Although those samples are macroscopically similar to the andesite coming from the Tarde River source, there are no geochemical analyses on archaeological basalt or andesite samples coming from the north section of the PPS Basin or from the Burmeister-Belgrano Basin. Taking into consideration the distribution of basalt plateaus at a regional level, we cannot assure that Tarde River supplied the entire region, although it has been recognized as far as in the Chacabuco River Basin, Chilean IX Region.

\subsubsection{Obsidian}

A historical issue in NW Santa Cruz province archaeological research was to unravel the origin of a fair quantity of black obsidian artefacts, cores, and flake debris identified in surface and stratigraphic lithic assemblages from the BB Basin, PPS Basin, and Ibañez River Basin (IX Region, Chile). Some evidences of obsidian pebbles near Cerro Pampa and De la Chispa Plateau were found between 1989 and 1995 (Espinosa \& Goñi 1999). Geochemical analyses performed on 67 archaeological obsidian samples from the entire province and 92 pebbles from this huge but disperse potential secondary source enabled the identification of three chemical types based on different percentages of rubidium, strontium, and barium: Pampa del Asador (PDA I), Cerro Pampa (PDA II), and Pampa de la Chispa (PDA III) (Stern 1999). Chemical composition and age of the archaeological samples correlates $89 \%$ with the secondary source named PDA I.

A higher basaltic plateau lies between Pampas del Asador and de la Chispa, both above $600 \mathrm{~m}$ ASL. Obsidian nodules can be found scattered on both plateaus and around Cerro Pampa, at the western edge of Pampa del Asador. Some authors have stated that there is a decrease in size of obsidian nodules in an east-west vector (Belardi et al. 2006). Recently, Franco et al. (2017) report a newly-discovered distal source of PDA more than $170 \mathrm{~km}$ southeast of Pampa del Asador, in the form of small pebbles no bigger than $48 \mathrm{~mm}$.

Many archaeological sites in Patagonia register obsidian which was identified as coming from Pampa del Asador, sometimes reaching distances of $800 \mathrm{~km}$ from the main source (e.g., Ambrústolo et al. 2012; Méndez et al. 2009; 2012; Stern 2004; 2018). 


\subsection{Archaeological sites}

\subsubsection{Cerro Casa de Piedra 7 (CCP7)}

This is one of several caves and rockshelters facing north on a volcanic rhyolitic hill. While the palaeolakes were at a high level the whole hill was configured as a peninsula entering the lake. CCP7 was once a big rockshelter, but ca. 3600 cal. years BP it suffered a series of rockfall episodes, sealing the west wing and turning it into a smaller cave. The total surface excavated is 19 square meters. CCP7 has occupations dated between ca. 12600 and $3600 \mathrm{cal}$. BP. Obsidian is the most commonly used raw material on this site. On the other hand, even if basalt or andesite is used throughout the whole sequence, its representation is always low. Basalt or andesite and obsidian are both non-local raw materials. The first comes from a distance of around $25 \mathrm{~km}$ and the latter comes from Pampa del Asador, located $40 \mathrm{~km}$ away from the site (Civalero \& Franco 2003). The category "Others" is composed mostly by rhyolite and other types of siliceous rocks. A large number of paintings are featured at this site and other caves on the same hill. The rock art in this area reflects similarities with earlier styles that were identified at Río Pinturas (Gradin et al. 1976) (Figure 2a).

\subsubsection{Milodon Norte 1 Cave (CMN1)}

This cave is oriented to the north-northwest, facing one of the many creeks that descend to Lake Pueyrredón. It is located in the northwest portion of the PPS Basin, $1.5 \mathrm{~km}$ away from the northern margin of the previously mentioned lake and $300 \mathrm{~m}$ ASL. During the existence of the great palaeolake, this cave would have been very close to its shoreline. CMN1 has the longest chronological sequence of the PPS Basin with occupations ranging from 8800 to 1800 cal. years BP. In most parts of the total $10 \mathrm{~m}^{2}$ that was excavated, a tephra layer was identified. This volcanic ash was macroscopically related by Stern to the 7900 cal. years BP eruption of the Hudson Volcano (personal communications with Charles Stern in 2018). Regarding the origin of the lithic raw materials used in this site, andesite from River Tarde's secondary source (the same source used at CI1) can be found $35 \mathrm{~km}$ away, while obsidian from Pampa del Asador is located $80 \mathrm{~km}$ away. Both are considered as non-local raw materials. There is rock art identified at this site but the features of the cave walls and the presence of cattle in the past have affected its conservation (Figure $2 b$ ).

\subsubsection{Cerro de los Indios 1 Rockshelter (CI1)}

This rockshelter lies on the northern face of a cliff facing the centre of a glacial plain left behind by the PPS palaeolake. The site has a special topographic setting, enabling a full visibility of the basin below and, in reverse, it is visible from long distances from all directions. The chronology of CI1 begins at ca. 4200 cal. years BP. Eighteen ${ }^{14} \mathrm{C}$ dates were used to isolate 5 statistical segregated chronological groups and two temporal blocks divided by a long hiatus of ca. 1000 years in the stratigraphic sequence which seems to be a chronological singularity of CI1 deposit (Guraieb 2004). Abundant archaeological evidence recovered from CI1 stratigraphic layers in nearly $40 \mathrm{~m}^{2}$ of excavated sediment enabled different intra-site approaches. Lithic technology mainly used three kinds of rocks: andesite, a local raw material, a variety of siliceous rocks, and obsidian (considered a non-local resource), which was brought in from Pampa del Asador, $50 \mathrm{~km}$ away from the site.

Along two differentiated sectors on the CI1 rock walls, a large number of paintings and engravings can be found, proving a close relationship with some of the latest Río Pinturas rock art styles (Gradin et al. 1976) (Figure 2c). 


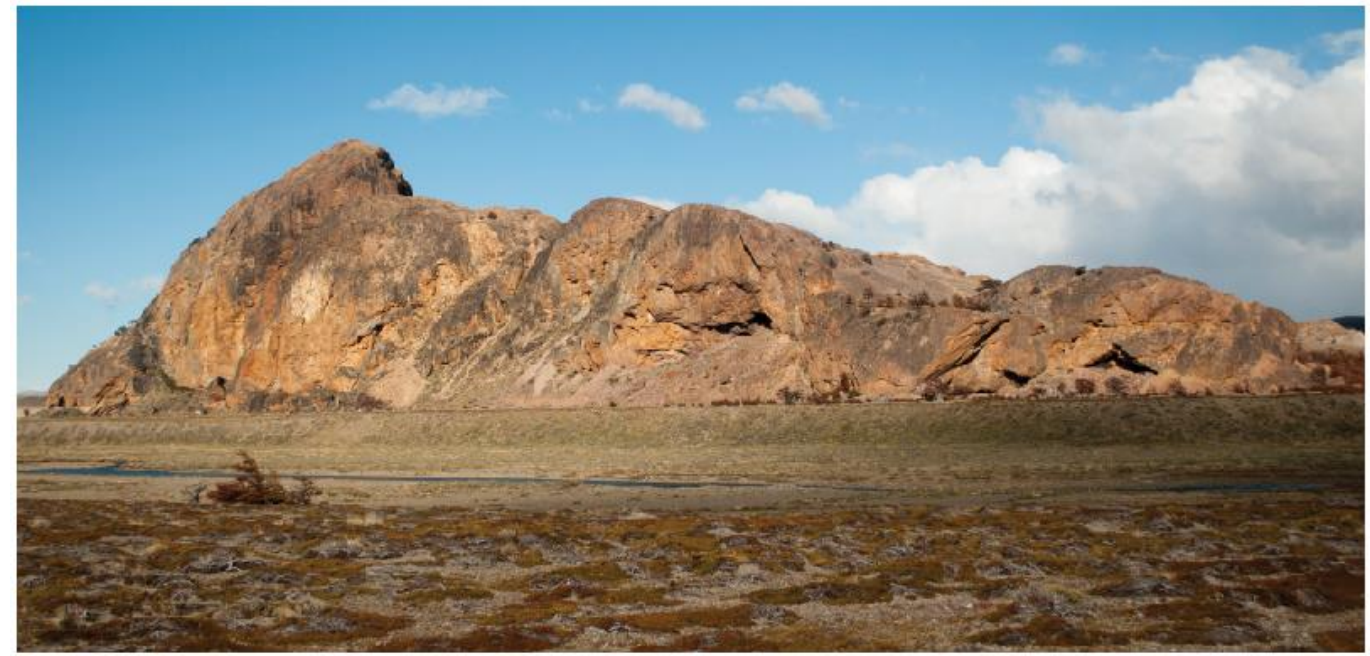

a)

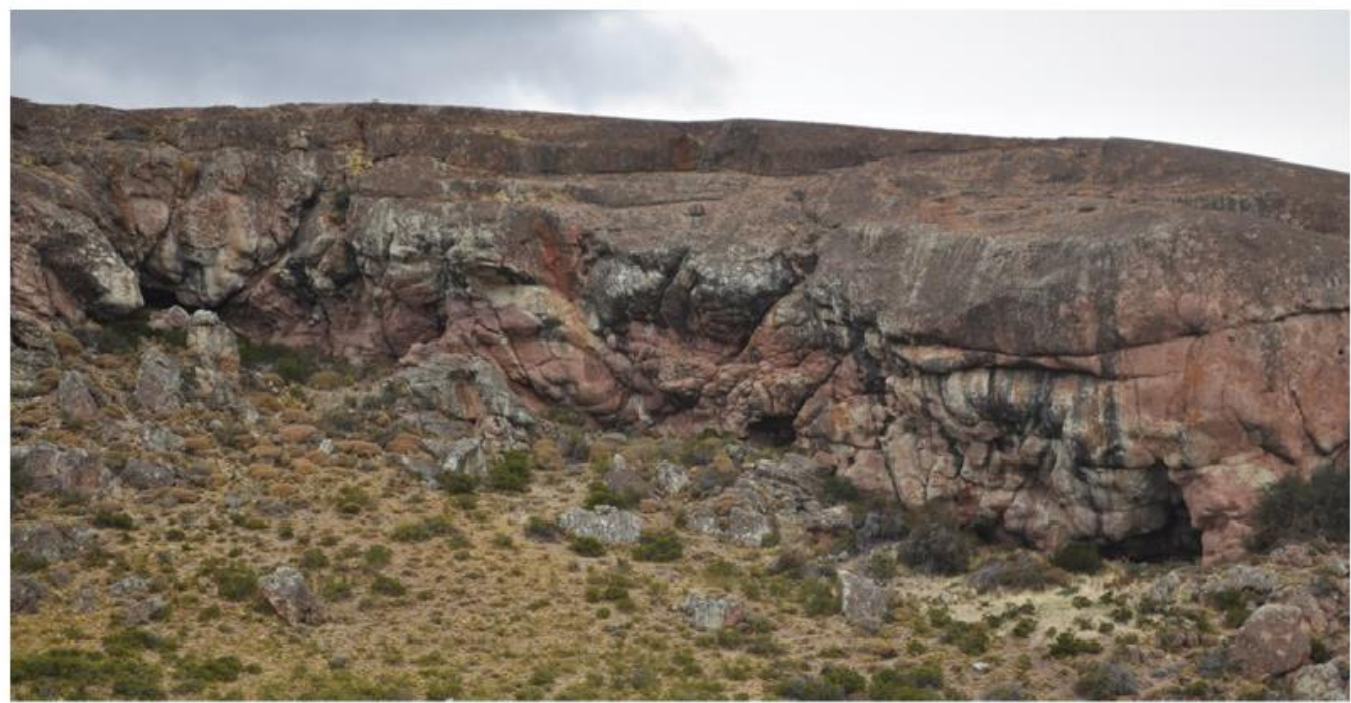

b)

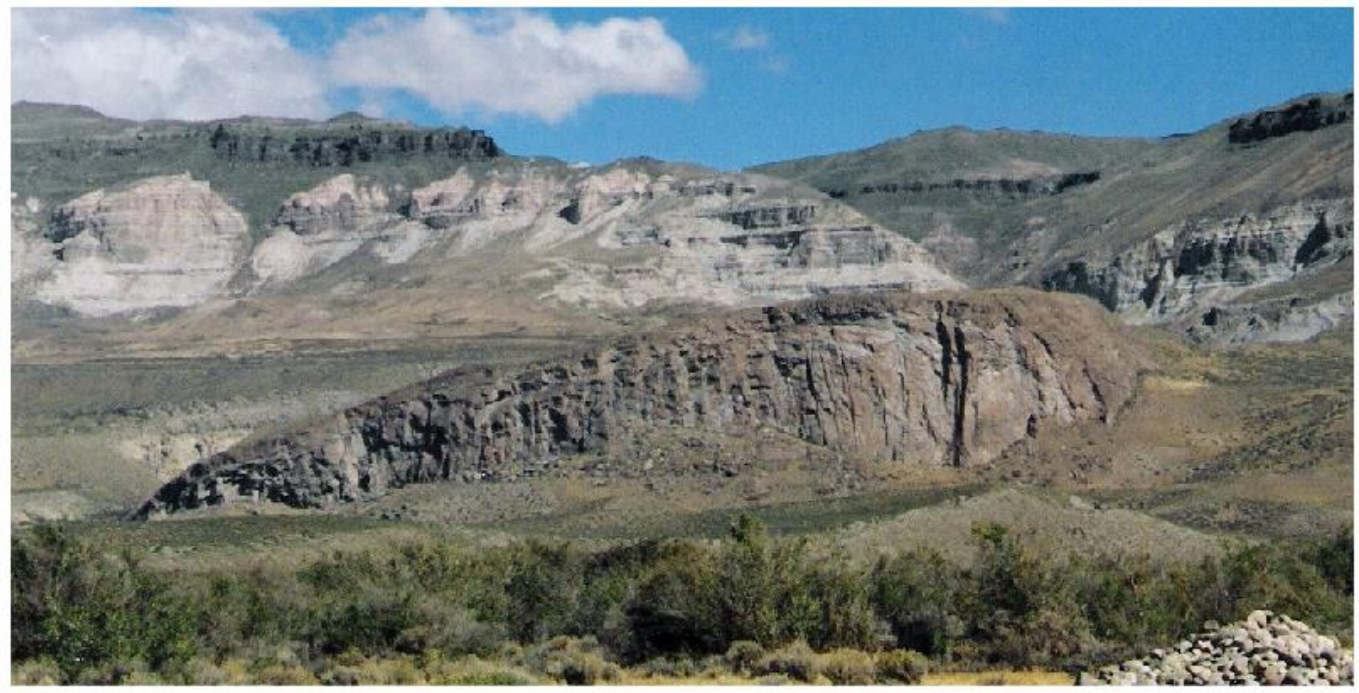

c)

Figure 2. General view of a) Cerro Casa de Piedra 7 (Burmeister-Belgrano Basin), b) Cueva Milodon Norte 1 and c) Cerro de los Indios 1 (Pueyrredón-Posadas-Salitroso Basin). 


\subsection{Chronology}

In order to arrange the lithic information, we built a series of tentative periods using 73 radiocarbon dates: 17 from $\mathrm{CI} 1,14$ from $\mathrm{CMN} 1$, and 42 radiocarbon dates from $\mathrm{CCP} 7 .{ }^{14} \mathrm{C}$ dates from the three sites were obtained in different laboratories and at different times. They were calibrated with CALIB 7.0.4 using the terrestrial calibration curve for the Southern Hemisphere SHCAL13 (Hogg et al. 2013), and a two sigma confidence. Three radiocarbon dates from CCP7 with standard deviations greater than 200 years were not included. For further information about chronological samples, see De Nigris et al. 2004 (CI1) and Sacchi et al. 2016 (CMN1 and CCP7).

We organized all available calibrated dates by mixing those that belonged to PPS and BB Basins in order to create six periods with an arbitrary extension of 2000 years. Gaps between periods were established considering that the midpoint of the last calibrated range of a period should fit completely within this period. At this stage, there has been no taphonomic bias analyses carried out for the last 2000 years, given that we are not conducting a chronological nor demographic study which could be constrained by time-dependent taphonomic biases (Méndez et al. 2015; Surovell \& Brantingham 2007) (Figure 3).

\section{Calibrated Age Ranges}

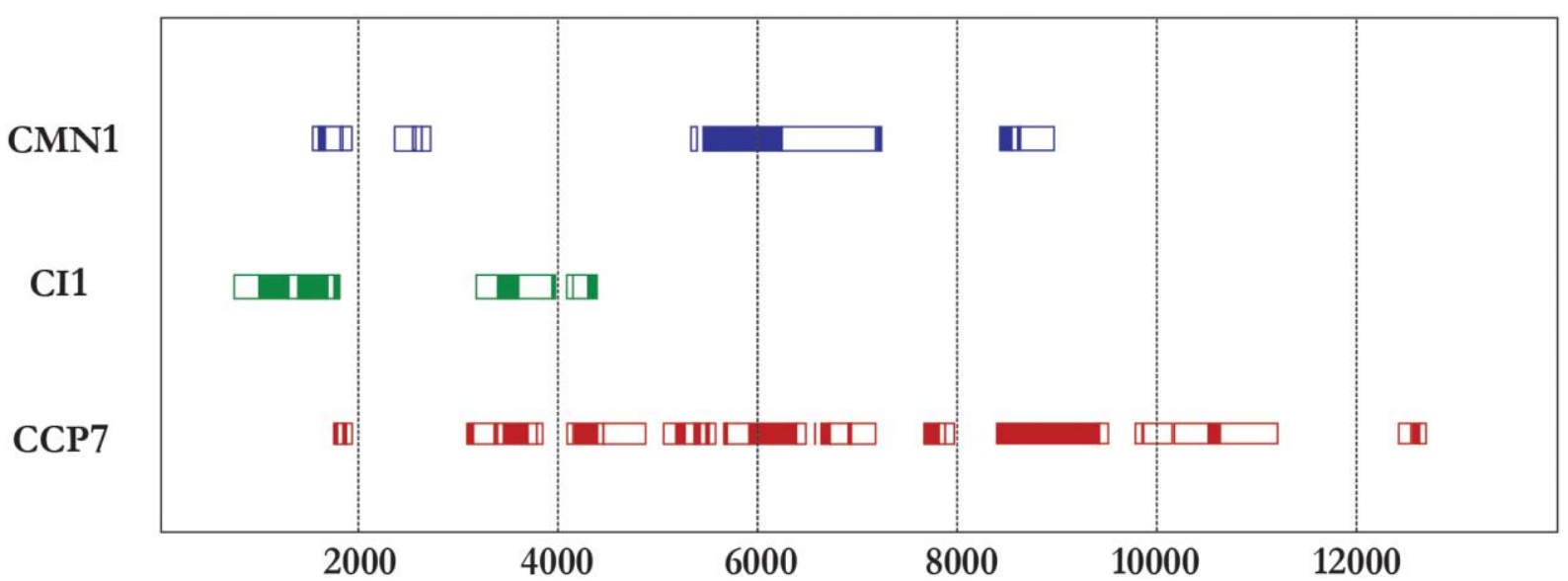

Figure 3. Statistical sum of probabilities for chronological calibrated ranges of CMI1, CI1 and CCP7.

Mid and early Holocene periods, best portrayed in CCP7 and CMN1, concentrate the largest number of radiocarbon dates (Civalero et al. 2007; Sacchi et al. 2016). Late Holocene is best represented in CI1, located in the middle of the PPS Basin. The chronological sequence of CI1 was divided in two Blocks (Initial and Recent) by a chronological hiatus of ca. 1500 years. This feature, which could be interpreted as an interruption in site occupations, appears to be a particularity of this deposit and does not imply the synchronic abandonment of other sites in the PPS Basin. During the time in which CI1 is not inhabited, in the northern sector of the PPS Basin, CMN1 has a very subtle occupation, with little archaeological evidence. In a similar way, between ca. 7500 and 8300 years BP, there is a probable occupation gap at the site CMN1 (PPS Basin), while CCP7 presents a more continuous sequence. All these characteristics should be better assessed in future research (Figure 3).

\subsection{Archaeological record considered}

This analysis encompasses samples of three typological artefact classes (sensu Aschero \& Hocsman 2004) from different periods of occupation of each site. These are unifacial and bifacial retouched stone tools (RA), unretouched stone tools with ultra-marginal traces 
(UAMT) (sensu Aschero 1975; 1983) and cores (C). From the total number of raw materials of each assemblage we isolated quantities and percentages of basalt or andesite and obsidian; the rest was labelled and quantified as "Others". A lithic analysis followed the macroscopic approach proposed by Aschero $(1975 ; 1983)$ as is widely used in Patagonian archaeology. We do not address here specific technological aspects of the analyzed lithic assemblages. However, there are some documented variations in different sectors of Patagonia that can be useful in terms of a broad spatial and temporal scale. The most prominent difference refers to the sizes and thicknesses of retouched artefacts. The sizes of the assemblages belonging to the earliest moments of occupations of Patagonia are larger when compared with those registered for the most recent periods (Civalero 2016).

\section{Results}

The following tables display a short summary of the raw material selection for each site, chronological period, and typological class category considered.

\subsection{Cerro Casa de Piedra}

Initial evidence of settlements at the Belgrano-Burmeister Basin comes from four archaeological contexts of CCP7, the oldest one stands directly on top of a layer of Pleistocene megafauna excrement. Lithic assemblages from all periods are characterized by high frequencies of obsidian, scarce basalt or andesite, and a third category composed, primarily by rhyolite and siliceous rocks. The values of each typological class may be interpreted as a sign of high occupation redundancy in every period. Nevertheless, it is evidence of a steep decline in lithic assemblages size in those contexts belonging to MidHolocene (4000 to 6000 cal. years BP) as well as a new growth towards the final occupations of CCP7 during the last period. Retouched artefacts are the most abundant category in every raw material and in every archaeological context. The prevalence of obsidian over basalt and andesite is maintained throughout the CCP7 sequence. In general terms, cores are scarce when compared to the rest of the categories, although obsidian cores predominate widely and those of basalt or andesite are practically absent (Table 1).

Table 1. Cerro Casa de Piedra 7 (CCP7) lithic assemblages by period. RA: Retouched artefact; C: core; UAMT: Unretouched artefact with marginal traces.

\begin{tabular}{lccccccccccccc}
\hline CCP7 & \multicolumn{3}{c}{ Basalt-Andesite } & \multicolumn{3}{c}{ Obsidian } & \multicolumn{3}{c}{ Others } & \multicolumn{3}{c}{ Totals } \\
\hline Period (BP) & R.A. & C. & UAMT & R.A. & C. & UAMT & R.A. & C. & UAMT & R.A. & C. & UAMT & Total \\
\hline $10000-12000$ & 45 & - & 2 & 202 & 15 & 68 & 159 & 10 & 40 & 406 & 25 & 110 & 541 \\
$8000-10000$ & 45 & - & 2 & 304 & 18 & 95 & 158 & 14 & 20 & 507 & 32 & 117 & 656 \\
$6000-8000$ & 14 & 1 & 1 & 116 & 9 & 30 & 118 & 13 & 12 & 248 & 23 & 43 & 314 \\
$4000-6000$ & 8 & - & - & 33 & 5 & 12 & 32 & 1 & 4 & 73 & 6 & 16 & 95 \\
$2000-4000$ & 22 & 2 & 13 & 151 & 11 & 86 & 188 & 11 & 58 & 361 & 24 & 157 & 542 \\
\hline Total & $\mathbf{1 3 4}$ & $\mathbf{3}$ & $\mathbf{1 8}$ & $\mathbf{8 0 6}$ & $\mathbf{5 8}$ & $\mathbf{2 9 1}$ & $\mathbf{9 4 6}$ & $\mathbf{4 9}$ & $\mathbf{1 3 4}$ & $\mathbf{1 5 9 5}$ & $\mathbf{1 1 0}$ & $\mathbf{4 4 3}$ & $\mathbf{2 1 4 8}$ \\
\hline
\end{tabular}

\subsection{Cueva Milodon Norte 1}

This site has smaller lithic assemblages when compared with CI1 and CCP7, having very low frequencies in several periods. Therefore, assemblages with less than 20 artefacts were not included for temporal trends graphics (Figure 4). Nevertheless, there is a slight increase during the 4000-6000 year period BP and a greater one during the final occupations at the site. There is a relatively high presence of retouched artefacts and, on the contrary, very few unretouched artefacts with marginal traces (Table 2). 


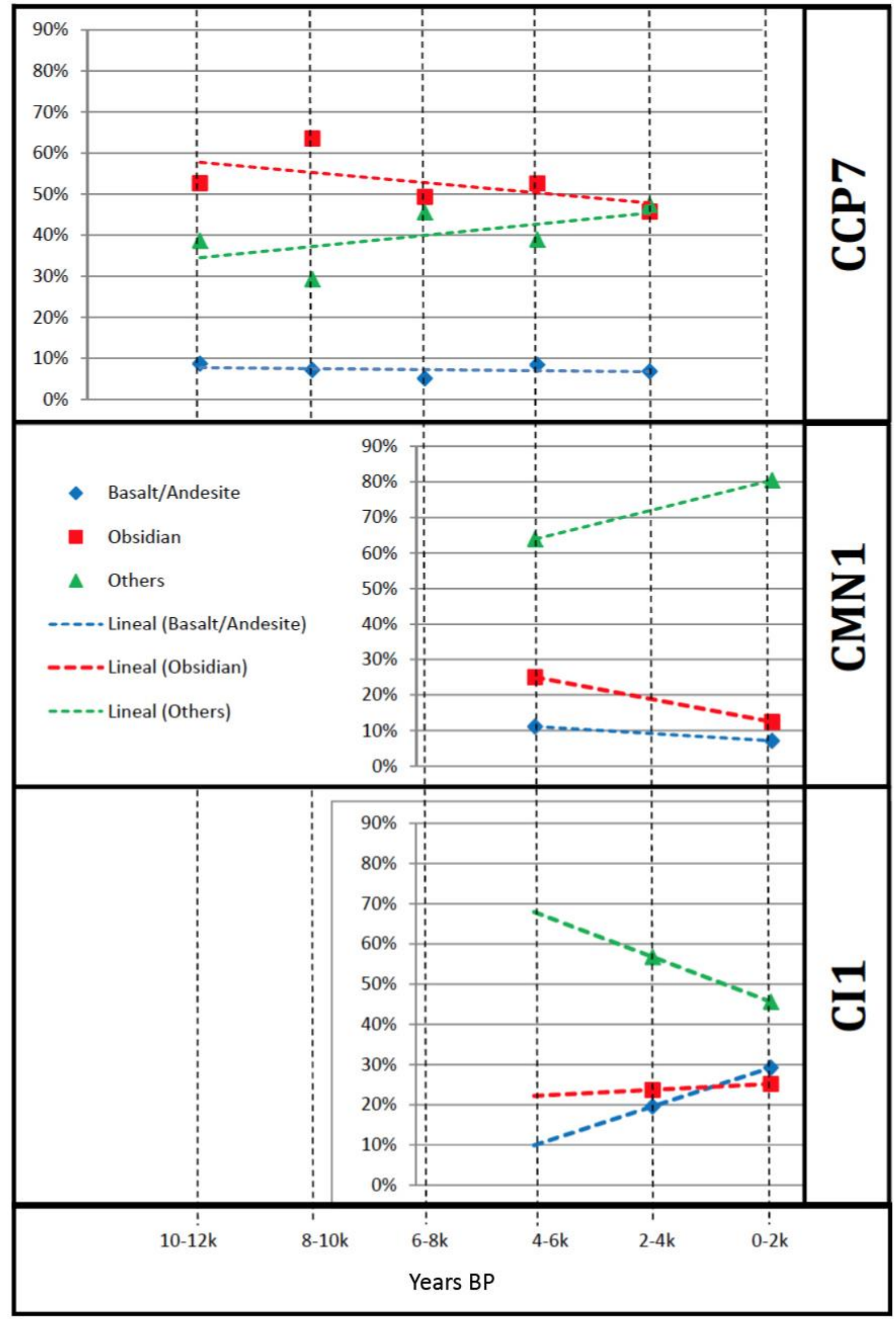

Figure 4. Selection of obsidian, andesite, and other raw materials throughout time with corresponding tendency lines. (a): CCP7; (b): CMN1; (c) CI1. 
Table 2. Cueva Milodon Norte 1 (CMN1) lithic assemblages by period. RA: Retouched artefact; C: core; UAMT: Unretouched artefact with marginal traces.

\begin{tabular}{lccccccccccccc}
\hline CMN1 & \multicolumn{3}{c}{ Basalt-Andesite } & \multicolumn{3}{c}{ Obsidian } & \multicolumn{3}{c}{ Others } & \multicolumn{3}{c}{ Totals } \\
Period (BP) & R.A. & C. & UAMT & R.A. & C. & UAMT & R.A. & C. & UAMT & R.A. & C. & UAMT & Total \\
\hline $8000-10000$ & 1 & - & - & 1 & - & - & 4 & - & 1 & 6 & - & 1 & 7 \\
$6000-8000$ & 3 & - & - & 1 & - & - & 11 & 2 & - & 15 & 2 & - & 17 \\
$4000-6000$ & 7 & - & 1 & 15 & - & 3 & 41 & 2 & 3 & 63 & 2 & 7 & 72 \\
$2000-4000$ & 3 & - & - & 5 & - & 1 & 10 & 1 & - & 18 & 1 & 1 & 20 \\
$0-2000$ & 12 & - & 4 & 23 & 1 & 4 & 173 & 5 & 3 & 208 & 6 & 11 & 225 \\
\hline Total & $\mathbf{2 6}$ & - & $\mathbf{5}$ & $\mathbf{4 5}$ & $\mathbf{1}$ & $\mathbf{8}$ & $\mathbf{2 3 9}$ & $\mathbf{1 0}$ & $\mathbf{7}$ & $\mathbf{3 1 0}$ & $\mathbf{1 1}$ & $\mathbf{2 0}$ & $\mathbf{3 4 1}$ \\
\hline
\end{tabular}

\subsection{Cerro de los Indios 1}

The basal context of CI1 (4000-6000 BP) has very few artefacts (n: 17). Therefore, it has not been taken into consideration to represent temporal tendencies (Figure 4). The data set (Table 3) shows values from different artefact classes grow towards the latter period, although with similar proportions between classes. Retouched artefacts are the most represented compared to the other artefactual classes, while cores are the less represented in all periods. This can be related to the estimated function of the site as a residential settlement, with fewer activities linked to lithic tools manufacture (Guraieb 2012). Although siliceous rocks dominate the raw material selection in all periods at CI1, values of andesite and obsidian begin to grow towards the end of the occupation (Table 3 ).

Table 3. Cerro de los Indios 1 (CI1) lithic assemblages by period. RA: Retouched artefact; C: core; UAMT: Unretouched artefact with marginal traces.

\begin{tabular}{lccccccccccccc}
\hline CI1 & \multicolumn{3}{c}{ Basalt-Andesite } & \multicolumn{4}{c}{ Obsidian } & \multicolumn{3}{c}{ Others } & \multicolumn{3}{c}{ Totals } \\
Period (BP) & RA & C & UAMT & RA & C & UAMT & RA & C & UAMT & RA & C & UAMT & Total \\
\hline $4000-6000$ & 4 & - & - & 4 & - & - & 9 & - & - & 17 & - & - & 17 \\
$2000-4000$ & 275 & 43 & 66 & 290 & 30 & 145 & 979 & 35 & 100 & 1544 & 108 & 311 & 1963 \\
$0-2000$ & 398 & 21 & 203 & 369 & 11 & 156 & 783 & 32 & 155 & 1550 & 63 & 514 & 2127 \\
\hline Total & $\mathbf{6 7 7}$ & $\mathbf{6 4}$ & $\mathbf{2 6 9}$ & $\mathbf{6 6 3}$ & $\mathbf{4 1}$ & $\mathbf{3 0 1}$ & $\mathbf{1 7 7 1}$ & $\mathbf{6 7}$ & $\mathbf{2 5 5}$ & $\mathbf{3 1 1 1}$ & $\mathbf{1 7 1}$ & $\mathbf{8 2 5}$ & $\mathbf{4 1 0 7}$ \\
\hline
\end{tabular}

\section{Discussion and final remarks}

Both basins had a very early initial occupation before the Pleistocene palaeolakes began to drain towards the oceans. The basal level of CCP7 (10690 \pm 72 years BP [UGAMSR00873], calibrated range 12537-12713) is the oldest context, of the end of Pleistocene. There is no available data for the same period in the PPS Basin. Its chronological sequence begins in the next period (8000-10000) in the northern portion of the basin. CMN1 basal level has $7982 \pm 45$ years BP [AA-101222], (calibrated range between 8632 and 8988 years). The first occupations of the southern portion of the same basin begin later on, towards the end of

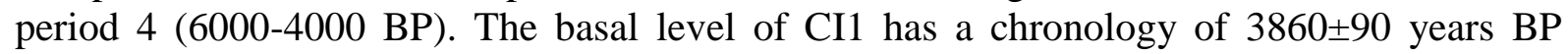
[LP455], (calibrated range between 3964 and 4440 years). In those moments, the palaeolake had already drained towards the Pacific Ocean and the southern part was available for human inhabitation.

\subsection{Period 1: 10000-12000 years BP}

The palaeolakes formed in the Belgrano-Burmeister and Pueyrredón-Posadas-Salitroso Basin during the Pleistocene-Holocene transition were at the highest level the initial populations would face. Human occupations were only found in one of the two Basins. CCP7 was located very near to the coastline of the BB palaeolake, which stood at $900 \mathrm{~m}$ ASL. 
The abundance of obsidian in all typological classes related to the use of other raw materials is clearly implying a low energy route to and from the Pampa del Asador source, not limited by the presence of the palaeolake, with an initial peopling coming from the east, where obsidian has its source. On the contrary, andesite has a poor proportional representation, absent in cores and with low frequency selection for the manufacture of UAMT. It may be interpreted as the difficulty of access to the southern sector of the PPS Basin where the only known source lies. Nevertheless, basalt or andesite could have come from secondary sources close to Pampa del Asador (Figure 1).

\subsection{Period 2: 8000-10000 years BP}

BB and PPS Basins had human settlements despite the fact that both palaeolakes levels remained the same than during the previous period. CCP7 has five contexts belonging to this lapse and, in the northern sector of the PP Basin, CMN1 presents two initial contexts. At CCP7 a high proportional representation of obsidian persists in all typological classes, absence of andesite cores, and very low frequencies in the rest of the categories. CMN1 was also located very near to the coast, at $300 \mathrm{~m}$ ASL. Because CMN1 lithic assemblages are very small, it is difficult to obtain any reliable information.

\subsection{Period 3: 6000-8000 years BP}

According to Horta et al. (2009), the palaeolake of the BB Basin began to drain ca.6900 years ago, while the one on the PPS Basin began to drain almost a thousand years later. Both processes were progressive, and had level fluctuations. Another important geologic event during this period was the eruption of the Hudson Volcano (7800 cal. BP) (Stern et al. 2016), which could have also restricted the available space (Aschero et al. 2018). The PPS Basin should have been the most affected, given the proximity to the volcano.

Three contexts from CCP7 and two from CMN1 belong to this period. Lithic assemblages are small, especially in CMN1. Although there are high frequencies of obsidian at CCP7, other raw materials are also used with higher intensities than in previous periods. The sole exception is the unretouched artefacts with marginal traces; these can only be found in obsidian. As in Periods 1 and 2, there are low frequencies of andesite.

While frequencies of lithic evidence increase slightly in CMN1 contexts compared with the preceding period, this growth is only evident for other raw materials (others).

\subsection{Period 4: 4000-6000 years BP}

During the Mid-Holocene, both basins progressively achieved the current lacustrine configuration, with a chain of smaller lakes where the big palaeolakes had once been. In spite of the addition of the initial context of CI1 (PPS Basin) in this period there are no high frequencies of lithic evidence in any of the three considered sites.

Lithic evidence from CCP7 belongs to a single context. In all typological classes and among all raw materials, obsidian displays the greatest proportional representation. In opposition, the selection of andesite decreases, without cores and UAMT.

In this period, the northern part of the PPS Basin appears to be more redundantly occupied than before. CMN1 has eight contexts, each of them with very low quantities of archaeological evidence. All typological classes are present. Andesite artefacts are the less abundant, followed by those made of obsidian and "others" raw materials as the most represented.

The oldest settlement at CI1 (4001-6000 BP) is level 17, a single context with very few artefacts, therefore making it difficult to evaluate its significance. Nevertheless, there is a 
restricted and almost equal utilization of andesite (local raw material) and obsidian (nonlocal) in retouched artefacts, the only typological class in the entire assemblage. This characteristic persists almost unmodified throughout the whole site's occupation sequence (Table 3).

\subsection{Period 5: 2000-4000 years BP}

This is the last period in which these three sites are present, although they all account for different tendencies in raw material selection. There is an increase of sample size in the five archaeological contexts from CCP7, with high and similar frequencies of obsidian and other raw materials. On the other hand, due to sample size growth, andesite is represented in every typological class although with few artefacts.

Although the number of contexts for this period decreases, in CMN1 a slight relative increase of andesite and obsidian presence can be observed. The distribution of raw materials amongst typological classes remains approximately similar as in previous periods, without andesite or obsidian cores, and very scarce UAMT.

The eight contexts, corresponding to the initial effective occupation of CI1, show a restricted use of andesite, while obsidian (non-local) maintains a stable trend with regards to the previous period. There is a clear selection of raw materials related to certain typological classes; for instance, andesite cores or obsidian unretouched artefacts with marginal traces (UAMT). The category of retouched artefacts is led by "others" (different varieties of siliceous rocks) (Guraieb 2012).

\subsection{Period 6: 0-2000 years BP}

Four contexts from CMN1 and eight from CI1 belong to this late Holocene period. Sample sizes of each context are bigger than in previous periods, which indicate a more stable occupation of both banks of the PPS Basin. In CMN1, the selection of other raw materials is predominant, followed by obsidian and andesite, with low percentages. There are no andesite core and only one of obsidian.

In the latest period of occupation of CI1, percentages of andesite and obsidian become almost equivalent. The use of andesite grows at the expense of other raw materials, substituting them in the manufacture of the same artefactual groups. These characteristics pose an interesting difference with the selection of raw materials observed in CMN1, where other raw materials such as siliceous rocks or rhyolite have a better proportional representation (Figure 4).

\section{Summary}

Regarding the impact of the evolution of both palaeolakes in the availability of andesite and obsidian, we observe different situations for each archaeological site based on the analysed data.

a) As previously mentioned, in the Burmeister-Belgrano Basin, obsidian is the most represented raw material, in spite of not being of local acquisition. This preeminence stands in all periods indicating that the route to and from Pampa del Asador source had no impediments. Not even the largest size of the palaeolake affected the circulation between the southern and eastern sectors of the basin, which is evident in CCP7 lithic data (Table 1). On the contrary, basalt or andesite does not exceed $10 \%$ at any time, with a flat tendency line. Although nodules of this raw material are found at the same locations as obsidian, this provenance cannot be assured since there are no geochemical analyses done to basalt or andesite samples from CCP7 and Pampa del Asador. Should any variety of basalt or andesite 
come from this source or nearby areas, as established by some authors (Belardi et al. 2006; Espinosa \& Goñi 1999), it would not have been selected with the same intensity as obsidian, and would have been oriented to the production of only a few types of artefacts. The tendency line representing the evolution of the remaining raw materials throughout time starts to climb towards the latest moments at CCP7 probably because local landscapes began to be available for circulation and procurement of a greater variety of resources (Figure 4).

b) During the initial occupations at CMN1 (northern sector of PPS basin) the palaeolake level was below $300 \mathrm{~m}$ ASL, with a shoreline very near to the site. That is why some routes to Pampa del Asador were not available, thus increasing the distance to this source. In addition, the Río Tarde andesite source was inaccessible at this time due to its location on the southern margin of the palaeolake. Through time, other raw materials prevailed in CMN1 lithic assemblages. With lower values, there is an increasing tendency to the selection of obsidian, and conversely, a decreasing tendency regarding basalt or andesite. Its provenance is uncertain, although a part of it could come from the Rio Tarde source (Figure 4).

c) CI1 shows a very frugal utilization of obsidian, with figures of around $24 \%$ in all periods and a slight increment towards the latest moments of occupation. Since its access was never restricted, the selection is intentionally oriented to the manufacture of certain kinds of artefacts. The use of andesite, a local raw material obtained very near to CI1, appears nevertheless to be as selective as the use of obsidian. Only towards the end of the chronological sequence of the site do the percentages increase, at the expense of a decrease in the use of other raw materials, such as siliceous rocks, of what can be inferred a greater stability in occupations (Guraieb 2012).

Previous studies have compared the percentage of representation and the circulation of raw materials, both for the Pueyrredón-Posadas-Salitroso basin (Cassiodoro et al. 2004; Guraieb et al. 2006 among others) and for the lakes Belgrano-Burmeister (Aschero et al. 1992; Bellelli \& Civalero de Biset 1989). However, this is the first attempt to integrate information from three sites (caves and rockshelter) in both basins whose chronological sequences overlap in time, from the late Pleistocene to the late Holocene. This comparison also enabled the evaluation of the incidence of those palaeolakes modelling the circulation of raw materials in both basins over time. Pending studies include geochemical analyses of different basalt or andesite varieties and a more detailed look on the "Others" category, which in each site includes different lithologies.

We focused the analysis on palaeoenvironmental and palaeogeographical changes which could have posed a constraint for hunter-gatherers movement across the Holocene. In this case, constraint imply long detours or substitution of raw materials; because palaeolakes were no physical barrier during most of the time. On the other hand, raw material availability does not depend only upon landscape distribution of suitable rocks but also upon other social considerations that without any doubt changed over time.

\section{Acknowledgements}

We are grateful to Agustina Papú and Alejo García Guraieb who helped us improve the writing in English. We wish to thank our co-workers, and the people of Lago Posadas, Perito Moreno, and the PNPM for helping us during our many years of field work. We also owe a big favour to the owners of Estancias El Bagual, Cruz del Sur and Lago Posadas (PPS basin) and to the National Parks Administration. Research was funded by CONICET, UBA, and INAPL. We dedicate this article to the memory of our dear friend and colleague Dr. Mariana De Nigris. She will always be with us. 


\section{References}

Ambrústolo, P., Zubimendi, M.A. \& Stern, C.R. 2012, Explotación de obsidiana negra en la costa norte de Santa Cruz (Patagonia, Argentina). Cazadores Recolectores del Cono Sur, 6: 77-86. (in Spanish) ("Explotation of black obsidian on the north coast of Santa Cruz (Argentine Patagonia)") URL: https://www.academia.edu/6446769

Aragone, A., Bourlot, T., Cassiodoro, G. \& Re, A. 2004, Análisis comparativo del registro arqueológico en médanos del interior de Santa Cruz. In: Miradas. Trabajos de las $V$ Jornadas de Jóvenes Investigadores en Ciencias Antropológicas (Carballido, M., Pisarello, C. \& Re, A., Eds.), Instituto Nacional de Antropología y Pensamiento Latinoamericano (INAPL), Buenos Aires: p. 327-345. (in Spanish) ("Comparative analysis of the atchaeological record in dunes of the interior of Santa Cruz")

Aschero, C.A. (1975), Ensayo para una clasificación morfológica de los artefactos líticos aplicada a estudios tipológicos comparativos. Informe de Investigación al CONICETManuscript, Consejo Nacional de Investigaciones Científicas y Técnicas (CONICET), Buenos Aires, 162 p. (in Spanish) ("Morphological classification of lithic artefacts essay, applied to comparative typological studies")

Aschero, C.A. (1983), Revisión del ensayo para una clasificación morfológica de los artefactos líticos aplicada a estudios tipológicos comparativos. Manuscrito de Cátedra, Universidad de Buenos Aires, Buenos Aires, 80 p. (in Spanish) ("Revision of the essay of a morphological classification of lithic artefacts, applied to comparative typological studies")

Aschero, C.A., Bellelli, C., Civalero, M., Goñi, R., Guraieb, A.G. \& Molinari, R. 1992, Cronología y tecnología en el Parque Nacional Perito Moreno: ¿Continuidad o reemplazos? Arqueología, 2: 89-106. (in Spanish) ("Timeline and technology in the Perito Moreno National Park: Continuity or replacements?")

URL: http://repositorio.filo.uba.ar/handle/filodigital/6948

Aschero, C.A., Bellelli, C. \& Goñi, R. 1993, Avances en las investigaciones arqueológicas en el Parque Nacional Perito Moreno. Cuadernos del Instituto Nacional de Antropología y Pensamiento Latinoamericano, 14: 143-170. (in Spanish) ("Advances in archaeological research in Perito Moreno National Park")

URL: https://revistas.inapl.gob.ar/index.php/cuadernos/article/view/428

Aschero, C.A., Bozzuto, D.L., Civalero, M.T., de Nigris, M.E., Fernández, N.L., Maveroff, N. \& Sacchi, M. 2019, Se nos viene la noche. El volcán Hudson y su influencia en el NO de Santa Cruz: Integrando perspectivas arqueológicas. In: Arqueología de la Patagonia. El pasado en las arenas (Gómez Otero, J., Svoboda, A. \& Banegas, A., Eds.), Instituto de Diversidad y Evolución Austral, Puerto Madryn: p. 12 p. (in Spanish) ("Night is coming. Hudson volcano and its influence in NW Santa Cruz: An integration of archaeological perspectives")

Aschero, C.A., Bozzuto, D.L., Civalero, M.T., de Nigris, M.E., di Vruno, A., Dolce, V., Fernández, N.L., González, L. \& Sacchi, M. 2007, Nuevas evidencias sobre las ocupaciones tempranas en Cerro Casa de Piedra 7. In: Arqueología de FuegoPatagonia. Levantando Piedras, Desenterrando Huesos y Develando Arcanos (Morello, F., Martinic, M., Prieto, A. \& Bahamonde, G., Eds.), Cequa, Punta Arenas, Chile: p. 569-576. (in Spanish) ("New evidence on early occupations at Cerro Casa de Piedra 7") 
Aschero, C.A., Goñi, R.A., Civalero, M.T., Molinari, R., Espinosa, S.L., Guraieb, A.G. \& Bellelli, C.T. 2005, Holocenic Park: Arqueología del Parque Nacional Perito Moreno. Anales de la Administración de Parques Nacionales, 17: 71-119. (in Spanish) ("Holocenic Park: Archeology of the Perito Moreno National Park")

Aschero, C.A. \& Hocsman, S. 2004, Revisando cuestiones tipológicas en torno a la clasificación de artefactos bifaciales. In: Temas de Arqueología. Análisis lítico (Acosta, A., Loponte, D. \& Ramos, M., Eds.), Departamento de Ciencias Sociales, Universidad Nacional de Luján, Lujan, Buenos Aires: p. 7-25. (in Spanish) ("Reviewing typological issues related to bifacial artefacts classification")

Belardi, J.B., Tibero, P., Stern, C.R. \& Sunico, A. 2006, Al este del Cerro Pampa: Ampliación del área de disponibilidad de obsidiana al este de Pampa del Asador. Intersecciones en Antropología, 7: 27-36. (in Spanish) ("East of Cerro Pampa. Expansion of obsidian availability area to the east of Pampa del Asador")

Bellelli, C.T. \& Civalero de Biset, M.T. 1989, El sitio Cerro Casa de Piedra 5 (CCP5) y su territorio de explotación de recursos minerales (Parque Nacional Perito Moreno, Pcia. Santa Cruz). Arqueología Contemporánea, 2(2): 53-63. (in Spanish) ("The site Cerro Casa de Piedra 5 (CCP5) and its mineral resources exploitation territory")

Binford, L. 1981, Bones: Ancient men and modern myths. Academic Press, New York, 328 p.

Bozzuto, D.L. 2008, Inferencias topográficas sobre la base de un muestreo superficial en el sector Noreste del Lago Pueyrredón-Cochrane. Magallania, 36(1): 117-123. (in Spanish) ("Topographical inferences based on surface sampling in the Northeast sector of Lake Pueyrredón-Cochrane")

URL: https://scielo.conicyt.cl/scielo.php?script=sci_abstract\&pid=S071822442008000100009

Bozzuto, D.L. 2011, Cazadores, lugares y movilidad en Patagonia. Análisis de conjuntos líticos de superficie en el norte del Lago Pueyrredón-Cochrane, Argentina (Editorial Académica Española ed.). Editorial Académica Española, Riga (Latvia), 264 p. (in Spanish) ("Hunters, places and mobility in Patagonia. Analysis of surface lithic assemblages in the north of Lake Pueyrredon - Cochrane, Argentina")

Carozza, J.-M., Micu, C., Mihail, F. \& Carozza, L. 2012, Landscape change and archaeological settlements in the lower Danube valley and delta from early Neolithic to Chalcolithic time: A review. Quaternary International, 261: 21-31. doi:10.1016/j.quaint.2010.07.017

Cassiodoro, G., Aragone, A. \& Re, A. 2004, Más allá de los chenques... Registro arqueológico de sitios a cielo abierto en la cuenca de los lagos Salitroso y PosadasPueyrredón. In: Contra viento y marea. Arqueología de Patagonia (M. T. Civalero, Fernández, P. \& Guraieb, A.G., Eds.), Instituto Nacional de Antropología y Pensamiento Latinoamericano, Buenos Aires: p. 325-338. (in Spanish) ("Beyond the chenques... Archaeological record of open-air sites in the Salitroso and PosadasPueyrredón lakes basin") 
Cassiodoro, G., Rindel, D., Goñi, R., Re, A., Tessone, A., García Guraieb, S., Belardi, J., Espinosa, S., Nuevo Delaunay, A., Dellepiane, J., Flores Coni, J., Guichón, F., Martinez, C. \& Pasqualini, S. 2013, Arqueología del Holoceno Medio y Tardío en Patagonia Meridional: Poblamiento humano y fluctuaciones climáticas. Diálogo Andino, 41: 5-23. (in Spanish) ("Archaeology of Middle and Late Holocene in Southern Patagonia: Human population and climatic fluctuations") doi:10.4067/s071926812013000100002

Civalero, M.T. 2016, Propuesta metodológica para el análisis del material lítico del sitio Playa Cisnes 2, provincia de Santa Cruz, Patagonia Argentina. In: Arqueología de la Patagonia: de Mar a Mar (Mena, F., Ed.), Nire Negro, Coyhaique: p. 235-244. (in Spanish) ("Methodological proposal for the analysis of the lithic material of the site Playa Cisnes 2, province of Santa Cruz, Patagonia Argentina")

Civalero, M.T., Borrazzo, K., Bozzuto, D., di Vruno, A., Dolce, V., Limbrunner, P. \& Lucero, M. 2007, ¿Últimas excavaciones en Cerro Casa de Piedra 7, Santa Cruz? In:

Arqueología Argentina en los Inicios de un Nuevo Siglo (F. Oliva, de Grandis, N. \& Rodríguez, J., Eds.), Universidad Nacional de Rosario (UNR), Rosario: p. 329-335. (in Spanish) ("Last excavations at Cerro Casa de Piedra 7, Santa Cruz?")

Civalero, M.T. \& Franco, N.V. 2003, Early human occupations in western Santa Cruz Province, southernmost South America. Quaternary International, 109-110: 77-86. doi:10.1016/s1040-6182(02)00204-5

Espinosa, S. \& Goñi, R. 1999, Viven! Una fuente de obsidiana en la Provincia de Santa Cruz. In: Soplando en el viento: Actas de las Terceras Jornadas de Arqueología de la Patagonia (Belardi, J., Fernández, P., Goñi, R., Guraieb, G. \& de Nigris, M.E., Eds.), Universidad Nacional del Comahue e Instituto Nacional de Antropología y Pensamiento Latinoamericano, Buenos Aires \& Neuquén: p. 177-188. (in Spanish) ("They live! A source of obsidian in the Santa Cruz province")

Franco, N.V., Brook, G.A., Cirigliano, N.A., Stern, C.R. \& Vetrisano, L. 2017, 17 de Marzo (Santa Cruz, Argentina): A new distal source of Pampa del Asador type black obsidian and its implications for understanding hunter-gatherer behavior in Patagonia. Journal of Archaeological Science: Reports, 12(4): 232-243. doi:10.1016/j.jasrep.2017.01.037

García Guraieb, S., Goñi, R. \& Tessone, A. 2015, Paleodemography of Late Holocene huntergatherers from Patagonia (Santa Cruz, Argentina): An approach using multiple archaeological and bioarchaeological indicators. Quaternary International, 356: 147158. doi:10.1016/j.quaint.2014.09.054

Glasser, N.F., Harrison, S., Winchester, V. \& Aniya, M. 2004, Late Pleistocene and Holocene palaeoclimate and glacier fluctuations in Patagonia. Global and Planetary Change, 43(1-2): 79-101. doi:10.1016/j.gloplacha.2004.03.002

Goñi, R. 1988, Arqueología de momentos tardíos en el Parque Nacional Perito Moreno (Santa Cruz, Argentina). In: Precirculados del IX Congreso Nacional de Arqueología Argentina, Universidad de Buenos Aires (UBA), Buenos Aires: p. 65-68. (in Spanish) ("Archaeology of late moments in the Perito Moreno National Park, Santa Cruz, Argentina") 
Goñi, R. 2000, Arqueología de momentos históricos fuera de los centros de conquista y colonización: Un análisis de caso en el sur de la Patagonia. In: Desde el País de los Gigantes. Perspectivas Arqueológicas en Patagonia (Espinosa, S., Ed.), Universidad Nacional de la Patagonia Austral (UNPA), Río Gallegos: p. 283-296. (in Spanish) ("Archaeology of historical moments outside the centres of conquest and colonization: A case analysis in southern Patagonia")

Goñi, R. 2002, Fechados radiocarbónicos y registro arqueológico en la cuenca de los lagos Salitroso/Posadas (Santa Cruz). Cuadernos del Instituto Nacional de Antropología y Pensamiento Latinoamericano, 19: 666-668. (in Spanish) ("Radiocarbon dates and archaeological record in the basin of Salitroso / Posadas lakes [Santa Cruz]")

González, M.A. 1990, Probable evolución climática de la República Argentina durante el Pleistoceno Tardío y el Holoceno. In: 2th. Reunión Anual del International Geoscience Programme- Project Nro. 281: Climas Cuaternarios de América del Sur (González, M.A., Ed.), Escuela de Administración, Finanzas e Instituto Tecnológico (EAFIT), Medellín, Colombia: p. 1-9. (in Spanish) ("Probable climatic evolution of the Argentine Republic during the Late Pleistocene and the Holocene")

González, M.A. 1992, Paleoambientes del Pleistoceno Tardío - Holoceno Temprano en la Cuenca de los Lagos Belgrano y Burmeister (471400/480 Sur, 721300Oeste), Santa Cruz. Informes Técnicos. Fundación Carl C. zon Caldenius, 9: 1-7. (in Spanish) ("Palaeoenvironments of the Late Pleistocene - Early Holocene in the Belgrano and Burmeister lakes basin")

Gradin, C.J., Aschero, C.A. \& Aguerre, A. 1976, Investigaciones arqueológicas en la Cueva de las Manos, Estancia Alto Río Pinturas, Pcia. de Santa Cruz. Relaciones de la Sociedad Argentina de Antropología, 10: 201-270. (in Spanish) ("Archaeological researches in Cueva de las Manos, Estancia Alto Pintura, Santa Cruz province") URL: http://hdl.handle.net/10915/25285

Guraieb, A.G. 2004, Before and after the hiatus. Lithic technology in Cerro de los Indios 1 rockshelter, south Patagonia, Argentina. Before Farming. Anthropology and Archaeology of Hunter-Gatherers, 2004(2): 19 p. doi:10.3828/bfarm.2004.2.3

Guraieb, A.G. 2012, Tendencias tecnológicas y de diseño de artefactos líticos de las ocupaciones del Holoceno Tardio de Cerro de los Indios 1 (CI1), lago Posadas, provincia de Santa Cruz. Ph.D thesis at the Facultad de Filosofía y Letras, Universidad de Buenos Aires, Buenos Aires, 424 p. (in Spanish) ("Technological and design trends of lithic artefacts of the Late Holocene occupations at Cerro de los Indios 1 (CI1),Lake Posadas, Santa Cruz province")

Guraieb, A.G., Cassiodoro, G., Re, A. \& Tivoli, A.M. 2006, Distancia a la fuente de aprovisionamiento y variabilidad en los conjuntos líticos de la cuenca de los lagos Pueyrredón-Posadas-Salitroso (Patagonia cordillerana argentina). In: Sociedad Prehistórica, recursos abióticos y territorio (Martínez Fernández, G., Morgado Rodríguez, A. \& Afonso Marrero, J.A., Eds.), Fundación Ibn al Jatib de Estudios y Cooperación Cultural y Universidad de Granada, Granada: p. 195-210. (in Spanish) ("Distance to the source and variability in lithic assemblages of the PueyrredónPosadas-Salitroso lake basin [Argentine Cordilleran Patagonia]") 
Hogg, A., Hua, Q., Blackwell, P.G., Niu, M., Buck, C.E., Guilderson, T.P., Heaton, T.J., Palmer, J.G., Reimer, P.J., Reimer, R.W., Turney, C.S.M. \& Zimmerman, S. 2013, SHCAL13 Southern Hemisphere Calibration, 0-50,000 Years cal BP. Radiocarbon, 55(4): 1-15. doi:10.2458/azu_js_rc.55.16783

Horta, L.R. \& Aschero, C.A. 2010, Evidencias de un paleolago Pleistoceno tardío-Holoceno temprano en el área de lago Pueyrredón, noroeste de la provincia de Santa Cruz. In: Libro de Actas XVII Congreso Nacional Arqueología Argentina (Barcena, J.R. \& Chiavazza, H., Eds.), Universidad Nacional de Cuyo - Consejo Nacional de Investigaciones Científicas y Técnicas (UNCuyo - CONICET), Mendoza: p. 1929-1934. (in Spanish) ("Evidence of a late Pleistocene-early Holocene palaeolake in the area of Lake Pueyrredón, northwest of the province of Santa Cruz")

Horta, L.R. \& Console Gonella, C.A. 2009, Análisis paleoambiental y reconstrucción paleoclimática mediante isótopos estables en el área del lago Pueyrredón, Provincia de Santa Cruz - Argentina. In: Terceras Jornadas de Jóvenes Investigadores Universidad Nacional de Tucuman, Universidad Nacional de Tucumán, San Miguel de Tucumán: p. 492-502. (in Spanish) ("Palaeoenvironmental analysis and palaeoclimatic reconstruction using stable isotopes in the area of Lake Pueyrredón, Province of Santa Cruz Argentina")

Horta, L.R., Georgieff, S.M., Aschero, C.A. \& Goñi, R.A. 2017, Paleolacustrine records from Late Pleistocene - Holocene in the Perito Moreno National Park, Argentinian Patagonian Andes. Quaternary International, 436: 8-15. doi:10.1016/j.quaint.2017.01.001

Horta, L.R., Marcos, M.A., Bozzuto, D.L., Mancini, M.V. \& Sacchi, M. 2016, Paleogeographic and paleoenvironmental variations in the area of the Pueyrredón, Posadas and Salitroso lakes, Santa Cruz Province, Argentina, during the Holocene and its relationship with occupational dynamics. Palaeogeography, Palaeoclimatology, Palaeoecology, 449: 541-552. doi:10.1016/j.palaeo.2016.02.051

Mahlburg Kay, S., Ramos, V.A. \& Marquez, M. 1993, Evidence in Cerro Pampa volcanic rocks for slab-melting prior to ridge-trench collision in southern South America. The Journal of Geology, 101(6): 703-714. doi:10.1086/648269

McCulloch, R.D., Bentley, M.J., Purves, R.S., Hulton, N.R.J., Sugden, D.E. \& Clapperton, C.M. 2000, Climatic inferences from glacial and palaeoecological evidence at the last glacial termination, southern South America. Journal of Quaternary Science, 15(4): 409-417. doi:10.1002/1099-1417(200005)15:4<409::aid-jqs539>3.0.co;2-\#

Méndez, C.A., Blanco, J.F. \& Quemada, C. 2007, Selección de matrices e intensidad de usoreavivado en los raspadores del Valle del Chacabuco (transecta occidental de Patagonia Central). In: Arqueología Argentina en los Inicios de un Nuevo Siglo Vol. 1 (Oiva, F., de Grandis, N. \& Rodriguez, J., Eds.), Rosario: Laborde Libros Editor, Santa Fe, Argentina: p. 587-598. URL: https://www.academia.edu/3019906/

Méndez, C.A., Gil, A., Neme, G., Nuevo Delaunay, A., Cortegoso, V., Huidobro, C., Durán, V. \& Maldonado, A. 2015, Mid Holocene radiocarbon ages in the Subtropical Andes $\left(\sim 29^{\circ}-35^{\circ} \mathrm{S}\right)$, climatic change and implications for human space organization. Quaternary International, 356: 15-26. doi:10.1016/j.quaint.2014.06.059 
Méndez, C.A., Stern, C.R. \& Reyes, O.R. 2009, Transporte de obsidianas a lo largo de los Andes de Patagonia central Cazadores-recolectores del Cono Sur, 3(2008-2009): 51-68. (in Spanish) ("Obsidian transport along the Andes of central Patagonia Aisén, Chile") URL: https://www.academia.edu/1868433

Méndez, C.A., Stern, C.R., Reyes, O.R. \& Mena, F. 2012, Early Holocene long-distance obsidian transport in central-south Patagonia. Chungará (Arica), 44(3): 363-375. doi:10.4067/s0717-73562012000300001

Molina, M.J. 1971, Arqueología patagónica, arte rupestre austral. Antiquitas, 12-13: 24-30. (in Spanish) ("Patagonic archaeology, southern rock art")

URL: https://racimo.usal.edu.ar/id/eprint/524

Morales, M., Barberena, R., Belardi, J.B., Borrero, L., Cortegoso, V., Durán, V., Guerci, A., Goñi, R., Gil, A., Neme, G., Yacobaccio, H. \& Zárate, M. 2009, Reviewing humanenvironment interactions in arid regions of southern South America during the past 3000 years. Palaeogeography, Palaeoclimatology, Palaeoecology, 281(3-4): 283-295. doi:10.1016/j.palaeo.2008.09.019

Nami, H. 1992, El subsistema tecnológico de la confección de instrumentos líticos y la explotación de los recursos del ambiente: Una nueva guía de aproximación. Shincal, 2: 33-53. (in Spanish) ("Technological subsystem of lithic artefact manufacture and exploitation of environmental resources: A new approach guide")

de Nigris, M.E., Figuerero Torres, M.J., Guraieb, A.G. \& Mengoni Goñalons, G.L. 2004, Nuevos fechados radiocarbónicos de la localidad de Cerro de los Indios 1 (Santa Cruz) y su proyección areal. In: Contra viento y marea. Arqueología de Patagonia (Civalero, M.T., Férnandez, P. \& Guraieb, A.G., Eds.), Instituto Nacional de Antropología y Pensamiento Latinoamericano, Buenos Aires: p. 537-544. (in Spanish) ("New radiocarbon dates from Cerro de los Indios 1 [Santa Cruz] and its areal projection")

Pereyra, F. \& Guraieb, G. 1998a, Estudios geoarqueológicos en el sitio Cerro de los Indios 1, Lago Posadas, Santa Cruz. In: Actas del X Congreso Latinoamericano de Geología Vol. 1, Congreso Latioamericano de Geología, Buenos Aires: p. 307-312. (in Spanish) ("Geoarchaeological studies in Cerro de los Indios 1, Lago Posadas, Santa Cruz")

Pereyra, F. \& Guraieb, G. 1998b, Procesos de formación y modificación de sitios en aleros: Cerro de los Indios 1 (Lago Posadas, Santa Cruz). Arqueología, 8: 101-126. (in Spanish) ("Formation processes and modification of sites in rock shelters: Cerro de los Indios 1 (Lago Posadas, Santa Cruz)")

Pereyra, F.X. (1997), Geoarqueología del alero Cerro de los Indios y zona del lago Posadas, provincia de Santa Cruz. Internal Report, Internal Report, Buenos Aires, 15 p. (in Spanish) ("Geoarcheology of Cerro de los Indios Rockshelter and the Lake Posadas zone, Santa Cruz province")

Ramos, V. (1982), Descripción geológica de las Hojas 53a Monte San Lorenzo y 53b Monte Belgrano, provincia de Santa Cruz. unpublished report, Servicio Geológico Nacional, Buenos Aires, 78 p. (in Spanish) ("Geological description of 53a Monte San Lorenzo and 53b Monte Belgrano maps, province of Santa Cruz")

Ramos, V., Mahlburg Kay, S. \& Singer, B. 2004, Las adakitas de la cordillera Patagónica: Nuevas evidencias geoquímicas y geocronológicas. Revista de la Asociación Geológica Argentina, 59(4): 693-706. (in Spanish) ("Adakites from the Patagonian mountain range: New geochemical and geochronological evidences") 
Re, A. 2006, Uso del espacio en el sector oeste de la cuenca de los lagos Pueyrredón, Posadas y Salitroso: Una aproximación tecnológica. Graduate thesis at the Facultad de Filosofía y Letras, Departamento de Ciencias Antropológicas, Universidad de Buenos Aires, Buenos Aires, 96 p. (in Spanish) ("Use of space in the western sector of the Pueyrredón, Posadas and Salitroso lakes basin: A technological approach")

Riggi, J.C. 1957, Resumen geológico de la zona de los lagos Pueyrredón y Posadas, provincia de Santa Cruz. Revista Asociación Geológica Argentina, 12(2): 65-96. (in Spanish) ("Geological summary of the Pueyrredón and Posadas lakes area, Santa Cruz Province")

Sacchi, M., Bozzuto, D.L., Horta, L.M., Fernández, N.L., de Nigris, M.E., Civalero, M.T. \& Aschero, C.A. 2016, Dataciones y circulación humana: Posibles influencias de las fluctuaciones del sistema lacustre Pueyrredón Posadas durante el Holoceno. Andes, 27(2). (in Spanish) ("Radiocarbon dates and human circulation: Possible influences of the fluctuations of the lake system Pueyrredón Posadas during the Holocene") URL: http://nnn.redalyc.org/articulo.oa?id=12752113004>

Stern, C.R. 1999, Black obsidian from central-south Patagonia, chemical characteristics, sources and regional distribution of artefacts. In: Soplando en el viento. Actas de las III Jornadas de Arqueología de la Patagonia (Civalero, M.T., Fernandez, P.M. \& Guraieb, G., Eds.), Instituto Nacional de Antropología y pensamiento Latinoamericano y Universidad Nacional del Comahue, Buenos Aires \& Neuquen: p. 221-234.

Stern, C.R. 2004, Obsidian in southern Patagonia: Review of the current information. In: Contra viento y marea. Arqueología de Patagonia (Civalero, T., Fernández, P. \& Guraieb, A.G., Eds.), Instituto Nacional de Antropología y Pensamiento Latinoamericano, Buenos Aires: p. 167-176.

Stern, C.R. 2018, Obsidian sources and distribution in Patagonia, southernmost South America. Quaternary International, 468: 190-205. doi:10.1016/j.quaint.2017.07.030

Stern, C.R., Moreno, P.I., Henríquez, W.I., Villa-Martínez, R., Sagredo, E., Aravena, J.C. \& de Pol-Holz, R. 2016, Holocene tephrochronology around Cochrane ( 47 $\left.{ }^{\circ} \mathrm{S}\right)$, southern Chile. Andean Geology, 43(1): 1-19. doi:10.5027/andgeoV43n1-a01

Surovell, T.A. \& Brantingham, P.J. 2007, A note on the use of temporal frequency distributions in studies of prehistoric demography. Journal of Archaeological Science, 34(11): 1868-1877. doi:10.1016/j.jas.2007.01.003

Tivoli, A. 2004, Recursos líticos y organización tecnológica en Cero de los Indios 1. Un enfoque desde el análisis de los desechos de talla. Graduate thesis at the Facultad de Filosofía y Letras, Departamento de Ciencias Antropológicas, Universidad de Buenos Aires, Buenos Aires, 147 p. (in Spanish) ("Lithic resources and technological organization at Cerro de los Indios 1. An approach using blank analysis") URL: http://repositorio.filo.uba.ar/handle/filodigital/969

Tivoli, A. 2005, Aprovechamiento de recursos líticos: La inserción regional de Cerro de los Indios 1 (Santa Cruz, Argentina). Relaciones de la Sociedad Argentina de Antropología, 30: 123-135. (in Spanish) ("Exploitation of lithic resources: the regional insertion of Cerro de los Indios 1 [Santa Cruz, Argentina]") URL: http://hdl.handle.net/10915/24935 